\title{
Elektromanyetik alanlara maruziyet gözlenen bazı biyokimyasal değişiklikler
}

sonrasi

\section{Observed some biochemical changes after electromagnetic fields exposure}

\section{Turan Akdağ*, Levent Sarıyıldız}

Biyokimya Anabilim Dalı (Dr. Turan Akdağ), Necmettin Erbakan Üniversitesi Meram Tip Fakültesi, TR-42090 Konya, Biyokimya Laboratuvarı (Dr. L. Sarıyıldı), Dr. Faruk Sükan Doğum ve Çocuk Hastanesi, TR-42060 Konya

\section{Özet}

Vücuda kolayca girebilen elektromanyetik alanların birçok yaşamsal olayı etkileyebileceği ileri sürülmektedir. Manyetik alan ve elektromanyetik dalga özellikleri, sağlik etkilerinin hangi doz parametreleri arasında olduğu ve bu parametrelerin eşik değerlerinin ne olması gerektiği günümüzde belirlenmesine rağmen, elektromanyetik alanlara maruz kalma miktarının tam olarak tespit edilememesi ve insan sağlığı üzerine yapılan çalışmaların yetersizliği gibi nedenlerle manyetik alanların insan sağlığı üzerine etkisi henüz net olarak ortaya konulamamıştır. Gittikçe artan manyetik alan maruziyetlerinin insan sağlığı üzerindeki etkilerini belirleyebilmek için ileri çalışmalara gereksinim vardır.

Anahtar sözcükler: Manyetik alan, eşik değeri, radyofrekans, elektromanyetik dalga

\begin{abstract}
It's proposed that electromagnetic fields can easily enter the body and can change some vitual conditions. Today magnetic field and electromagnetic wave properties which affect health and their threshold values proportional to the dose parameters are determined.But the virtual effect of magnetic field against health is not clearly known as the net exposure amount has not yet been determined and studies done on humans are scarce. Further studies are needed to find out the effect of magnetic field exposure against human health.
\end{abstract}

Keywords: Magnetic field, threshold value, radiofrequency, electromagnetic wave

Geliş tarihi/Received: 01 Şubat 2012; Kabul tarihi/Accepted: 04 Mayıs 2012

\section{*İletişim adresi:}

Dr. Turan Akdağ, Biyokimya Anabilim Dalı, Necmettin Erbakan Üniversitesi Meram Tip Fakültesi, TR-42090 Konya. E-posta: turanakdag570@gmail.com

\section{Giriş}

Elektromanyetik alan oluşturan aygıtların (baz istasyonları, mobil telefonlar, uydu antenleri v.s) ve etki alanlarının gün geçtikçe artmasıyla beraber zayıf veya güçlü radyofrekansın (RF) insan sağlığı üzerine etkisinin hangi boyutta olabileceği sorusunu akla getirmektedir. Vücuda kolayca girebilen manyetik alanın birçok yaşamsal olayı etkileyebileceği veya değiştirebileceği söylenebilir. Gelişen sağlık teknolojisiyle beraber (başta manyetik rezonans görüntüleme gibi) elektromanyetik alan oluşturan tıbbi cihaz ve ekipman sayısında artış gözlenirken olası yan etkilerinin açıklığa kavuşturulma ihtiyacı doğmuştur. RF şiddeti, maruz kalınan süre ve elektromanyetik alan kaynağına mesafe gibi nedenlerin olası etkiyi arttırdığı bildirilmektedir [1]. Birçok çalışmada elektromanyetik alanların baş dönmesi ve bulantı gibi vücutta olumsuz etkilere neden olduğu belirtilirken [2], bazı çalışmalarda Parkinson hastalığı, depresyon ve kanser olgularında olduğu gibi faydalı ve terapötik etkilerininde olduğu ifade edilmektedir [3]. 
Yeryüzünde mevcut olan doğal statik manyetik alanın varyasyonu 25-65 mT (mili Tesla) arasında değişmektedir [4]. İnsan vücudunda ise doğal manyetik alan, biyoelektrik yüklerin hareketlerinden oluşmaktadır. Biot-Savar Teorisine göre, hareketli elektrik yükleri belirli bir manyetizma oluşturur. Bu etkileşim canlılarda biyomanyetik alan oluşumuna neden olur [5]. Vücutta bulunan biyomanyetik alan ile diş çevrede bulunan güçlü elektromanyetik alanlar hücrede polarizasyona ve elektriksel dengenin bozulmasına neden olarak doku ve sistem bütünlügünü olumsuz etkileyebilmektedir [6]. Elektromanyetik alana maruz kalan hücrelerde reaktif oksijen türler oluşumunun arttığ ve bu artışın hücre dengesini olumsuz etkilediği vurgulanmaktadır [7].

İmmün sistemi hücrelerinin düşük frekanslı manyetik alanlara maruz kalmasıyla beraber bağışıklık sisteminin işleyişi ile ilgili hücresel değişimlerin açığa çıkabildiği ve bağışıklık sistemi üzerine etki ederek tümör oluşumunu hızlandırdığı bugün geniş kabul görmektedir [8]. Manyetik alanların; DNA, RNA ve protein sentezi [9], hücre bölünmesi [10], membrandan kalsiyum giriş çıkış1 ve sinyal iletimi [11] üzerine etkilerinin olduğu belirlenmiştir. Zayıf statik manyetik alanların insan sağlı̆ına zararlı olup olmadığı hakkında kesin bilgi olmamakla beraber, deney hayvanları üzerine yapılan çalışmalarda hormon ve enzim seviyesini değiştirebildiği, dokularda bulunan kimyasalların hareketini engelleyerek biyolojik değişikliklere neden olabileceği vurgulanmaktadır [12]. Yapılan bir çalışmada elektromanyetik alanların kalsiyum iyon kanal fonksiyonunda [13], protein kinaz C [14] ve nitrik oksit (NO) üretiminde [15] değişikliklere neden olduğu ifade edilmektedir. Sieron ve ark. [16], günlük 1,8-3,8 mT'lık manyetik alana maruz bırakılan ratların frontal korteksinde dopamin ve 5 hidroksitriptamin sentezinde artış olduğunu belirlemişlerdir. Dört hafta boyunca $900 \mathrm{MHz}$ (megahertz)'lik manyetik alana maruz bırakılan ratların ise kortizol seviyelerinde artış görülürken, testosteron seviyelerinde ise azalma gözlemlenmiştir [17].

Bazal metabolizma için oldukça önemli olan tiroid aktivitesi hipofizden salgılanan TSH (tiroid uyarıcı hormon) tarafından düzenlenir. Kronik olarak GSM telefon alanlarına maruz kalan erkek gönüllüler üzerinde yapılan bir çalışmada TSH salınımının \%21 azaldığı tespit edilirken [18], diğer bir çalışmada $1800 \mathrm{MHz}$ 'lik elektromanyetik alana maruz bırakılan sıçanların serum T3 ve T4 seviyelerinde anlamlı artış dikkat çekmektedir [19].

Deney fareleri ile statik manyetik alanda yapılan deneylerde embriyogenetik ve spermatogenetik aktivite bozuklukları tespit edilmiştir. $2450 \mathrm{MHz}$ 'lik statik manyetik alana maruz kalan ratların FSH ve LH değerlerinde bir değişiklik gözlenmezken, total testosteron seviyesinde anlamlı düşüş olduğu ifade edilmektedir [20]. Yapılan bir çalışmada 1,5 T'lık manyetik alana maruz kalan gönüllü insanlarda kalsiyum ve ferromanyetik özelliğe sahip olan demir düzeylerinde belirgin bir azalmanın olduğu tespit edilmiştir [21]. Diğer bir çalışmada 2,45 GHz frekanslı radyasyona 60 dakika maruz bırakılan genç ratların ise büyüme hormonu seviyesinde düşüş gözlenmiştir [22].

Elektromanyetik alana maruziyet sonrası vücutta melatonin salınımının azaldığı ve bu azalmaya bağlı olarak vücut biyoritminin bozulduğu öne sürülmektedir [23]. Melatoninin meme kanseri oluşumunda koruyucu rolü olduğundan, elektromanyetik alana maruziyetin herhangi bir nedenle oluşan meme kanserinin ortaya çıkışını hızlandırabileceği belirtilmektedir [24]. Diğer taraftan 2,9 mT'lık manyetik alana maruz kalan 20 gönüllü erkek bireyin prolaktin seviyesinde de düşüş olması ilginçtir [25].

Televizyon istasyonu çalışanlarının kolesterol seviyesi, radyo istasyonu çalışanlarına göre daha yüksek bulunmuştur [26]. Bu farklılık maruz kalınan manyetik alanın şiddetiyle açıklanabilirken bu sonuca göre manyetik alanın kolesterol seviyelerini etkilediği söylenebilir.

Yapılan bir diğer çalışmada Radyo-Tv yayın istasyonlarında çalışan teknisyenlerin östradiol, progesteron ve testosteron seviyelerinde yükselme gözlemlenmiştir [27]. Adrenal medulla tarafindan üretilen katekolaminlerin sentezi yoğun egzersiz, hipoglisemi 
ve stres gibi durumlarda artar. Uydu anteni operatörlerinin kronik manyetik alana maruziyet sonrası katekolamin sekresyonlarında artış belirlenirken [28], diğer bir çalışmada ise katekolamin ürünleri olan epinefrin ve nörepinefrin seviyelerinde de önemli artış görülmüştür [29].

Çalışmalar insanlar tarafından yapılan elektromanyetik kirliliğin (elektrosmog) genel keyifsizlik, boyunda sertlik, göğüs acısı, hafıza kaybı, baş ağrısı, sindirim ve dolaşım sorunları oluşturabildiğini göstermektedir [30]. Elektrosmog adı verilen ve teknolojinin beraberinde getirdiği elektromanyetik kirlenme, insan sağlı̆̆ını tehdit eden ciddi unsurlardan birisi olup beyinden hücrelere gönderilen sinyalleri engelleyerek immün sistem disfonksiyonuna neden olabileceği bildirilmektedir [31]. Beyin metabolizması için oldukça önemli olan serbest radikal dengesinin oksidatif hasar yönüne kayması sonucu biyomoleküller karsinojenik ajan olarak hareket edebilirler [32]. Ratlarla yapılan bir çalışmada manyetik alana maruziyet sonucu serbest radikal oluşumunda artış gözlemlenmiştir [33]. Moustafa ve ark. [34] cep telefonunun oluşturduğu manyetik alan maruziyeti sonucu serumda serbest radikal oluşumu gözlemlerken, eritrositlerde glutatyon peroksidaz ve süperoksit dismutaz aktivitelerinde azalma tespit etmişlerdir. Meral ve ark. [35] 900 MHz'lik manyetik alana maruz birakılan kobaylarda malondialdehit seviyesinde artış, katalaz ve glutatyon seviyelerinde düşüş gözlemlemişlerdir. Bu sonuç, maruziyet sonrası görülen lipid peroksidasyon ve serbest radikallerin artışıyla uyumluluk göstermektedir. Yapılan çalışmalar manyetik alana maruz bırakılan ratların enzimatik, lipolitik ve glukojenolitik aktivitelerinde değişikliklerin olduğunu ortaya koymaktadır [36]. Sihem ve ark. [37] 10 gün süreyle $128 \mathrm{mT}$ 'lık manyetik alana bıraktıkları dişi ratların plazma glukoz seviyesinin arttığını, trigliserid seviyesinin ise azaldığını gözlemlemişlerdir. Aynı çalışmada serum ALT seviyesinde herhangi bir farklılık saptanmazken AST ve LDH seviyelerinde artış belirlenmiştir. Manyetik alan maruziyet sonrası glukoz seviyesinde gözlenen bu artışın hiperglisemik hormonun (glukagon) salınımı ve/veya hipoglisemik hormonun (insülin) inhibisyonu sonucu oluştuğu ifade edilmektedir [38]. 3 mT'lık manyetik alana maruz bırakılan ratlarla yapılan bir diğer çalışmada ise AST seviyesinde değişiklik görülmemiştir [39]. Elektromanyetik alanların hücre ve doku üzerine etkisinin yanı sıra sinir, kardiyovasküler ve oküler sistemleri de etkileyebildiği bildirilmektedir [40]. $50 \mathrm{~Hz}$ ' lik manyetik alana maruz kalan gönüllü 63 bireyin kalp atım sayısı sağlıklı kontrollere göre oldukça düşük bulunmuştur [41]. 2 T'y1 aşan statik alanların çevresinde insanlar hareket ederken veya manyetik alana doğrudan maruziyette geçici duyusal etkiler görülebilir. Bunların en önemlileri baş ağrısı ve baş dönmesidir. Daha nadir olarak ağızda metalik tat ve retinada elektriksel 1şımalar görülebilir [42]. Zamanla değişen manyetik alanların genomik ve teratojenik etkilerine ilişkin bulgular statik manyetik ortamlarda elde edilmiş olan bulgular kadar belirgin olmamakla beraber deney hayvanlarında fetal gelişim sırasında iskelet ve lens anomalileri oluşturduğu bilinmektedir [43]. Gradient manyetik alanlar bazı nöroreseptörler üzerine inhibisyon etkisi gösterebilmektedir. Bu inhibisyon etkisi başta morfin olmak üzere bazı narkotik ilaçların analjezik etkilerinde düşüşe yol açmaktadır. Statik alanlarda ise bu tür etkilere rastlanılmamıştır [44].

Sonuç olarak; yapılan çalışmalarda elektromanyetik alanın vücutta biyolojik işleyişi olumsuz etkilediği belirtilirken bir o kadar çalışmada da olumsuz herhangi bir etkisinin olmadığı öne sürülmektedir. Çalışmaların geneline bakıldığında henüz elektromanyetik alanın vücutta biyolojik etkilerinin tam olarak ortaya konulamadığı görülmektedir. Elektromanyetik alanların insan sağlı̆̆ını hangi ölçüde etkilediğini anlayabilmek için ileri çalışmalara ihtiyaç vardır.

\section{Kaynaklar}

1. Budinger TF. MR safety: past, present, and future from a historical perspective. Magn Reson Imaging Clin N Am 1998; 6: 701-14.

2. Savitz DA, Loomis DP. Magnetic Field Exposure in Relation to Leukemia and Brain Cancer Mortality among Electric Utility Workers. Am J Epidemiol 1995; 
141: 123-34.

3. Bassett CA. Beneficial effects of electromagnetic fields. J Cell Biochem 1993; 4: 387-93.

4. Mansfield P, Grannell PK. NMR ‘diffraction'in solids? J Phys C-Solid state Phys 1973; 6: L422-6.

5. Sarvas J. Basic mathematical and electromagnetic concepts of the biomagnetic inverse problem. Phys Med Biol 1987; 32: 11-22.

6. Markov M. Can Magnetic and Electromagnetic Fields Be Used for Pain Relief. APS. Bulletin 2002; 12: 1-6.

7. Simkó M. Cell type specific redox status is responsible for diverse electromagnetic field effects. Current Medicinal Chemistry 2007; 14: 1141-52.

8. Simkó M, Mattsson MO. Extremely low frequency electromagnetic fields as effectors of cellular responses in vitro: possible immune cell activation. $\mathrm{J}$ Cell Biochem 2004; 93: 83-92.

9. Liboff AR, Williams T Jr, Strong DM, Wistar R Jr. Time-varying magnetic fields: effect on DNA synthesis. Science 1984; 223: 818-20.

10. Adey WR. Biological Effects of Electromagnetic Fields. J of Cell Biochem 1993; 51: 410-6.

11. Walleczek J. Electromagnetic field effects on cells of the immune system: the role of calcium signaling. FASEB J 1992; 6: 3177-85.

12. Anselmo CW, Pereira PB, Catanho MT, Medeiros MC. Effects of the electromagnetic field, $60 \mathrm{~Hz}, 3$ microT, on the hormonal and metabolic regulation of undernourished pregnant rats. Braz J Biol 2009; 69: 397-404.

13. Kavaliers M, Wiebe JP, Ossenkopp KP. Brief exposure of mice to $60 \mathrm{~Hz}$ magnetic fields reduces the analgesic effects of the neuroactive steroid, 3alphahydroxy-4-pregnen-20-one. Neurosci Lett 1998a; 257: 155-8.

14. Kavaliers M, Ossenkopp KP, Tysdale DM. Evidence for the involvement of protein kinase $\mathrm{C}$ in the modulation of morphine-induced 'analgesia' and the inhibitory effects of exposure to $60-\mathrm{Hz}$ magnetic fields in the snail, Cepaea nemoralis. Brain Res 1991; 554: 65-71.

15. Kavaliers M, Choleris E, Prato FS, Ossenkopp K. Evidence for the involvement of nitric oxide and nitric oxide synthase in the modulation of opioid-induced antinociception and the inhibitory effects of exposure to $60-\mathrm{Hz}$ magnetic fields in the land snail. Brain Res 1998b; 809: 50-7.

16. Sieroń A, Labus L, Nowak P, Cieślar G, Brus H, Durczok A, Zagził T, Kostrzewa RM, Brus R.Alternating extremely low frequency magnetic field increases turnover of dopamine and serotonin in rat frontal cortex. Bioelectromagnetics 2004; 25: 426-30.

17. Koyu A, Cesur G, Özgüner F, Elmas O. Cep telefonlarından yayılan $900 \mathrm{MHz}$ manyetik alanın serum kortizol ve testosteron hormonu üzerine etkisi. SDÜ T1p Fak Derg 2005: 12; 52-6.

18. de Seze R, Fabbro-Peray P, Miro L. GSM radiocellular telephones do not disturb the secretion of antepituitary hormones in humans. Bioelectromagnetics 1998; 19: 271-8.

19. Koyu A, Gökalp O, Özgüner F, Cesur G, Mollaoğlu H, Özer KA Çalışkan S. Subkronik $1800 \mathrm{MHz}$ elektromanyetik alan uygulamasının TSH, T3, T4, kortizol ve testosteron hormon düzeylerine etkileri. Genel Tıp Derg 2005; 15: 101-5.

20. Saygın M, Çalışkan S, Gümral N, Soydan M, Vural H. $2450 \mathrm{MHz}$ elektromanyetik radyasyonun sıçanların FSH, LH ve Total Testosteron seviyelerinde meydana getirdiği değişiklikler. SDÜ Tıp Fak Derg 2009; 16: 10-4.

21. Akdag T, Tiftik AM, Sarıyıldız L. 1,5 T (Tesla)'lık Manyetik Alana Maruziyet Sonrası Bazı Biyokimyasal Parametrelerde Gözlenen Değişiklikler. Marmara Med J 2011

22. Black DR, Heynick LN. Radiofrequency (RF) effects on blood cells, cardiac, endocrine, and immunological functions. Bioelectromagnetics 2003; 6: S187-95. 
23. WHO. Extremely Low Frequency Fields. Environmental Health Criteria WHO 2008.

24. Stevens RG, Davis S. The melatonin hypothesis: electric power and breast cancer. Environ Health Perspect 1996; 104: 135-40.

25. Woldanska-Okonska M, Karasek M, Czernicki J. The influence of chronic exposure to low frequency pulsating magnetic fields on concentrations of FSH, $\mathrm{LH}$, prolactin, testosterone and estradiol in men with back pain. Neuroendocrinol Lett 2004; 25: 201-6.

26. Vangelova K, Deyanov C, Israel M. Cardiovascular risk in operators under radiofrequency electromagnetic radiation. Int J Hyg Environ Health 2006; 209: 133-8.

27. Dasdağ S, Balci K, Kaya H, Celik MS. Hormone levels of people occupationally exposed to radiofrequencies. Biochem Arch 1999; 15: 255-60.

28. Boscol P, Di Sciascio MB, D'Ostilio S, Del Signore A, Reale M, Conti P, Bavazzano P, Paganelli R, Di Gioacchino M. Effects of electromagnetic fields produced by radiotelevision broadcasting stations on the immune system of women. Sci Total Environ 2001; 273: 1-10.

29. Vangelova K, Israel M, Mihaylov S. The effect of low level radiofrequency electromagnetic radiation on the excretion rates of stress hormones in operators during 24-hour shifts. Cent Eur J Public Health 2002; 10: 24-8.

30. Vangelova KK, Israel MS. Variations of melatonin and stress hormones under extended shifts and radiofrequency electromagnetic radiation. Rev Environ Health 2005; 20: 151-61.

31. Johansson O. Disturbance of the immune system by electromagnetic fields-A potentially underlying cause for cellular damage and tissue repair reduction which could lead to disease and impairment. Pathophysiology 2009; 16: 157-77.

32. Halliwell B, Gutteridge JMC. Free radicals in biology and medicine, 3rd ed. New York: Oxford University Press, 1999; pp: 936.

33. Ilhan A, Gurel A, Armutcu F, Kamisli S, Iraz M, Akyol O, Ozen S. Ginkgo biloba prevents mobile phone-induced oxidative stress in rat brain. Clin Chim Acta 2004; 340: 153-62.

34. Moustafa YM, Moustafa RM, Belacy A, Abou-El-Ela SH, Ali FM. Effects of acute exposure to the radiofrequency fields of cellular phones on plasma lipid peroxide and antioxidase activities in human erythrocytes. J Pharm Biomed Anal 2001; 26: 605-8.

35. Meral I, Mert H, Mert N, Deger Y, Yoruk I, Yetkin A, Keskin S. Effects of 900$\mathrm{MHz}$ electromagnetic field emitted from cellular phone on brain oxidative stress and some vitamin levels of guinea pigs. Brain Research 2007; 1169: 120-4.

36. Chernysheva ON. Status of the lipid phase of plasma membranes of the rat heart after repeated exposure to an alternate magnetic field of $50 \mathrm{~Hz}$ frequency. Kosm Biol Aviakosm Med 1990; 24: 30-1.

37. Chater S, Abdelmelek H, Sakly M, Pequinot JM, Ben RK. Effects of sub-acute exposure to magnetic field on blood hematological and biochemical parameters in female rats. Turk J Hematol 2006; 23: 182-7.

38. Gorczynska E, Wegrzynowicz R. Glucose homeostasis in rats exposed to magnetic fields. Invest Radiol 1991; 26: 1095-100.

39. Shalaby TE, Shawki MM. Biophysical and biochemical changes in the characteristics of rat blood exposed to combined alternating and static magnetic fields (in vivo study). Romanian J Biophys 2006; 16: 169-80.

40. Braune S, Riedel A, Schulte-Mönting J, Raczek J. Influence of a Radiofrequency Electromagnetic Field on Cardiovascular and Hormonal Parameters of the Autonomic Nervous System in Healthy Individuals. Radiation Research 2002; 158: 352-6.

41. Bortkiewicz A, Gadzicka E, Zmyślony M, Szymczak W. eurovegetative disturbances in workers exposed to $50 \mathrm{~Hz}$ electromagnetic fields. Int $\mathrm{J}$ Occup 
Med Environ Health 2006; 19: 53-60.

42. Nair I, Morgan MG, Florig HK, editors. Biological Effects of Power Frequency Electric and Magnetic Fields. The Minerva Group Inc, 2.ed USA Press 2002; pp: 96-8.

43. Zusman I, Yaffe P, Pinus H, Ornoy A. Effects of pulsing electromagnetic fields on the prenatal and postnatal development in mice and rats: in vivo and in vitro studies. Teratology 1990; 42: 157-70.

44. Prato FS, Ossenkopp KP, Kavaliers M, Sestini E, Teskey GC. Attenuation of morphine-induced analgesia in mice by exposure to magnetic resonance imaging: separate effects of the static, radiofrequency and time-varying magnetic fields. Magn Reson Imaging 1987; 5: 9-14. 